\title{
Research article \\ Proteinase-3 as the major autoantigen of C-ANCA is strongly expressed in lung tissue of patients with Wegener's granulomatosis
}

\author{
Holger Brockmann ${ }^{1}$, Andreas Schwarting1, Jörg Kriegsmann², Peter Petrow², Andreas Gaumann², \\ Klaus-Michael Müller ${ }^{3}$, Peter Robert Galle ${ }^{1}$ and Werner Mayet ${ }^{4}$
}

\author{
1'Department of Medicine, University of Mainz, Mainz, Germany \\ 2Institute of Pathology, University of Mainz, Mainz, Germany \\ Institute of Pathology, Professional Associations Hospital, Ruhr-University, Bochum, Germany \\ ${ }^{4}$ Center of Internal Medicine, Nordwest Hospital, Sanderbusch, Germany
}

Correspondence: Werner J Mayet, MD, Center of Internal Medicine, Nordwest Hospital, Sanderbusch, Germany. Tel: +49 4422 801101; fax: +49 4422 801130; e-mail: mayet@sanderbusch.de

\begin{abstract}
Proteinase-3 (PR-3) is a neutral serine proteinase present in azurophil granules of human polymorphonuclear leukocytes and serves as the major target antigen of antineutrophil cytoplasmic antibodies with a cytoplasmic staining pattern (c-ANCA) in Wegener's granulomatosis (WG). The WG disease appears as severe vasculitis in different organs (e.g. kidney, nose and lung). Little is known about the expression and distribution of PR-3 in the lung. We found that PR-3 is expressed in normal lung tissue and is upregulated in lung tissue of patients with WG. Interestingly, the parenchymal cells (pneumocytes type I and II) and macrophages, and not the neutrophils, express PR-3 most strongly and may contribute to lung damage in patients with WG via direct interaction with antineutrophil cytoplasmic antobodies (ANCA). These findings suggest that the PR-3 expression in parenchymal cells of lung tissue could be at least one missing link in the etiopathogenesis of pulmonary pathology in ANCA-associated disease.
\end{abstract}

Keywords: granuloma, in situ hybridization, pneumocytes, proteinase-3, Wegener's granulomatosis

\section{Introduction}

Proteinase-3 (PR-3) is a 29,000 Da neutral serine proteinase stored in the azurophil granules of polymorphonuclear leukocytes [1]. An increasing number of physiological and pathological properties of PR-3 have been reported. PR-3 has broad proteolytic activity and degrades a variety of extracellular matrix proteins, including fibronectin, type IV collagen and laminin $[2,3]$. PR-3 is identical to myeloblastin, which is a growth-promoting protein from myeloid cells [4]. Via a nonproteolytic mechanism, PR-3 has potent antimicrobial activity both against bacteria and fungi $[5,6]$. PR-3 was recently shown to induce apoptosis in cultured human endothelial cells [7]. PR-3 is also identical to the target antigen (antineutrophil cytoplasmic antibodies with a cytoplasmic staining pattern [c-ANCA]) associated with some systemic vasculitides such as WG and microscopic polyarteritis [8]. It is not yet known whether antineutrophil cytoplasmic antibodies

$\overline{A N C A}=$ antineutrophil cytoplasmic antibodies; APAAP = alkaline phosphatase-antialkaline phosphatase; c-ANCA = antineutrophil cytoplasmic antibodies with a cytoplasmic staining pattern; PR-3 = proteinase-3; WG $=$ Wegener's granulomatosis; RT-PCR $=$ reverse transcriptasepolymerase chain reaction. 
(ANCA) are directly involved in the pathogenesis of WG or are merely an epiphenomenon [9-11].

It has previously been thought that PR-3 expression was confined to the promyelocytic/myelocytic stage of hematopoiesis [12]. However, other cells are also capable of de novo synthesis of PR-3 mRNA. In vitro studies revealed that $\mathrm{PR}-3$ expression can be induced by cytokines in human endothelial cells $[13,14]$.

The lung is the organ most frequently involved in WG, and in some cases it is the only organ affected [15]. Given the potential importance of PR-3 in the pathogenesis of WG, we sought to define the expression pattern of $P R-3$ in lung tissue.

\section{Materials and methods Patients}

Normal tissues were obtained from five patients undergoing total pneumonectomy because of lung cancer. Tissue samples were snap-frozen in OCT Tissue Tek embedding medium (Leica Instruments, Hamburg, Germany).

We also obtained samples from five patients with WG and a proven lung involvement from the Institute of Pathology, University of Bochum/Clinic Bergmannsheil. All of these patients had a c-ANCA titer of more than 1:160 (indirect immunofluorescence on alcohol-fixed neutrophils).

\section{Northern blot analysis}

Total RNA was isolated from normal lung tissue with RNeasy (Quiagen, Hilden, Germany) and used for preparation of mRNA with the mRNA isolation kit (Hoffmann-La Roche, Grenzach-Whylen, Germany). The northern blot was performed as described by Müller-Ladner et al. [16].

\section{Preparation of the single-strand PR-3 RNA probe}

The cDNA sequences, used as probes for the mRNA of PR-3 components, were obtained by RT-PCR of total cellular mRNA of HL-60 cells, a myelomonocytic cell line [5]. The following primers were used in this study: PR-3 'sense', 5'-ATCGTGGGCGGGCACGAGGCG (at the beginning of exon 2, corresponding to bases +82 to +101 of the cDNA); and PR-3 'antisense', 5'-GCGGCCAGGGAACGAAAGTGCA (at the end of exon 4, corresponding to bases +553 to +582 ). The expected size of the fragment was 500 base pairs. The cDNA fragment was extracted and purified from a preparative gel using the Wizard PCR preps DNA purification system (Promega A 7170, CA, USA) and subcloned into the polylinker site of bluescript SK+ (Stratagene, CA, USA).

Antisense and sense RNA probes were transcribed by T3 and T7 RNA polymerase using a commercially available RNA transcription kit, according to the protocol recommended by the manufacturer (Stratagene). Probes were labeled with Digoxigenin-UTP (Hoffmann-La Roche).

\section{In situ hybridization}

Frozen sections $(4-6 \mu \mathrm{m})$ were cut, air-dried and fixed immediately in acetone for $15 \mathrm{~min}$. Formaldehyde-fixed sections were deparaffinized according to standard procedure. The sections were prepared according to the method of Müller-Ladner et al. [16].

\section{Immunological detection}

The slides were washed in Tris- $\mathrm{NaCl}(\mathrm{pH} \mathrm{7.6)}$ and incubated in Tris- $\mathrm{NaCl}$ containing $2 \%$ normal goat serum (to block nonspecific binding) for $30 \mathrm{~min}$ at room temperature, followed by incubation with antidigoxigenin-alkaline phosphatase-antibody complex (Hoffmann-La Roche) in Tris- $\mathrm{NaCl}(\mathrm{pH} \mathrm{7.6)}$ for 1 hour at room temperature. Then $45 \mu \mathrm{l}$ NBT (Boehringer Mannheim, Germany), $35 \mu \mathrm{l} \mathrm{BCIP}$ (Hoffmann-La Roche) and $24 \mu$ I Levamisole (Hoffmann-La Roche) were solved in $10 \mathrm{ml}$ polyvinyl alcohol in a darkened chamber. Two hundred milliliters were applied to each section and incubated for between 12 and 24 hours. The sections were then mounted with aqueous gel (Faramount; Dako, Glostrup, Denmark) or stored at $4^{\circ} \mathrm{C}$ in Tris $(\mathrm{pH} 7.6)$ for double-labeling by the alkaline phosphatase-anti-alkaline phosphatase (APAAP) method (see later).

Immunohistochemical double-labeling (APAAP method) Double-labeling was performed using the APAAP method, with monoclonal antibody against CD68 (macrophages mouse IgG, 1:50; Dako), CD15 (granulocytes IgM, 1:50; Dianova, Hamburg, Germany), CD20 (B lymphocytes, 1:50; Dako), CD3 (T lymphocytes, 1:50; Dako), and Cytokeratin 8 and 19 (mouse $\operatorname{lgG}_{1}, 1: 25$ and 1:200; Hoffmann-La Roche). Paraffin sections were prepared as described by Müller-Ladner et al. [16].

Double-labeling with biotin/fluorescence-coupled lectins PR-3 hybridized sections were overlaid with fluorescein isothiocyanate/biotin-coupled Bauhinia purpurea and Maclura pomifera lectin diluted 1:200 and 1:500, respectively, for $30 \mathrm{~min}$. Subsequently, slides were sequentially analyzed with light and fluorescent microscopy. The lectin of $B$. purpurea binds specifically to pneumocytes type I, whereas the lectin of M. pomifera binds to pneumocytes type II.

\section{Microscopic evaluation and semiquantitative analysis of PR-3 mRNA expression}

Sections were examined and photographed with a Leica Microscope DMRX (Leitz, Wetzlar, Germany). For quantitative analysis, a representative area between 1000 and 10,000 cells depending on the specimen was defined. In the representative areas, positive cells for PR-3 mRNA were scored in a semiquantitative fashion as follows: - , no positive cells; $(+),<5 \%$ of cells positive; + , between $5 \%$ and $30 \%$ of cells positive; ++ , between 30 and $60 \%$ of cells positive;,$+++>60 \%$ of cells positive. 


\section{Figure 1}

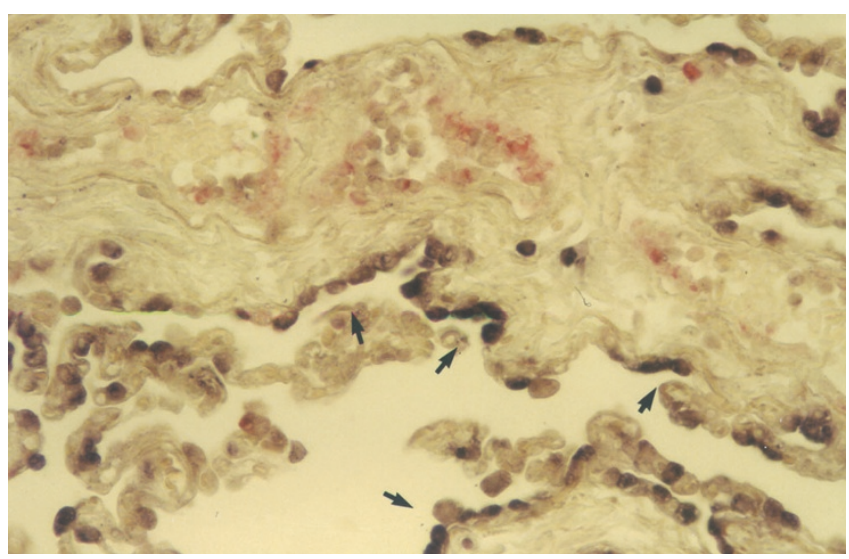

Proteinase-3 (PR-3) mRNA is expressed in alveolar epithelial cells in a human lung specimen (arrows). The expression of PR-3 mRNA was detected by nonradioactive in situ hybridization. Double-labeling with CD15 revealed some infiltrating neutrophils (red cells), different from the PR-3 mRNA expressing cells (magnification, $40 \times 2.5$ ).

\section{Results \\ Northern blot analysis}

We searched for PR-3 mRNA expression in different human tissues. We confirmed the presence of a strong single $1.3 \mathrm{~kb}$ band (the expected size for PR-3 mRNA), especially in lung tissue. We found just a very weak signal in the heart and brain, and could not detect a band in liver tissue (Supplementary Fig. 1).

\section{In situ hybridization for PR-3 mRNA in normal lung}

Nearly all PR-3 mRNA-positive cells were located at the alveolus covering cell layer (Fig. 1). PR-3 mRNA expression was mostly focused in areas showing macrophages in alveoles. The results obtained by in situ hybridization were reproducible in all biopsies. No hybridization signals were detected in the control experiments using a sense RNA probe (Supplementary Fig. 2).

\section{Characterization of PR-3 mRNA-positive cells in normal lung}

With regard to the histomorphological appearance and localization of the PR-3-positive cells, these cells appeared to be mostly pneumocytes. Double-staining with fluorescent lectins of $M$. pomifera and B. purpurea lectins confirmed the PR-3 mRNA expression in pneumocytes type I and II (Figs 2 and 3). Double-staining with markers for granulocytes and macrophages revealed that the majority of the PR-3 mRNA-positive cells were different from these cells (Fig. 1). Only a few CD68-positive and CD15-positive cells also showed a signal for PR-3 mRNA (Fig. 4).
Figure 2

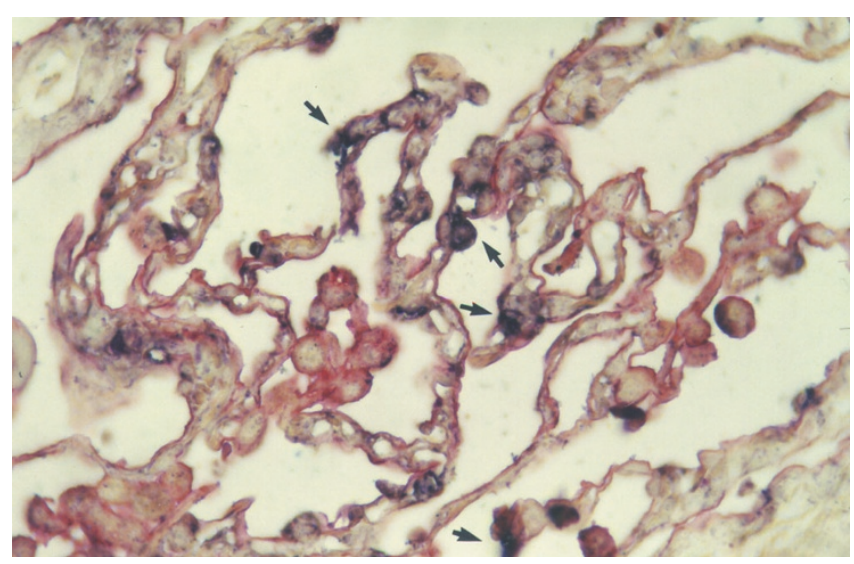

Proteinase-3 (PR-3) mRNA is expressed in pneumocytes type I in human lung tissue (arrows). The expression of PR-3 mRNA was detected by nonradioactive in situ hybridization, and the pneumocytes type I were detected by double-labeling with biotin-labeled lectins of Bauhinia purpurea (magnification, $60 \times 2.5$ ).

\section{In situ hybridization for PR-3 mRNA in lung tissue of WG patients}

We studied lung tissue from five patients with histologically and clinically proven WG and lung involvement. We found a very pronounced PR-3 expression throughout the whole slide in all cases. In comparison with the normal lung tissue where the PR-3 expression was confined to just a few spots, the expression in WG tissue was nearly ubiquitous (Fig. 5). We also observed a strong positive PR-3 mRNA signal at the sites of granulomas, inflammatory infiltration and vasculitis (Supplementary Fig. 3).

To obtain a semiquantitative estimation of PR-3 expression difference, we counted all cells positive for PR-3 mRNA. We found an approximately double to threefold PR-3 expression in WG tissues compared with normal lung tissue (Table 1).

Characterization of PR-3 mRNA-positive cells in WG tissue We found PR-3 mRNA expression mostly in pneumocytes type I and II. In comparison with normal tissue, however, there was a higher number of infiltrating, PR-3 expressing cells, different from pneumocytes.

Double-staining with different markers (CD20, CD3, CD15, and CD68) for inflammatory cells such as B cells, $T$ cells, granulocytes and macrophages helped in the characterization of these cells. We detected B cells in some secondary lymphoid follicles and a few scattered in the tissue. $T$ cells were virtually absent in the tissue. The B cells and T cells did not express PR-3 mRNA at all. Apart 
Figure 3

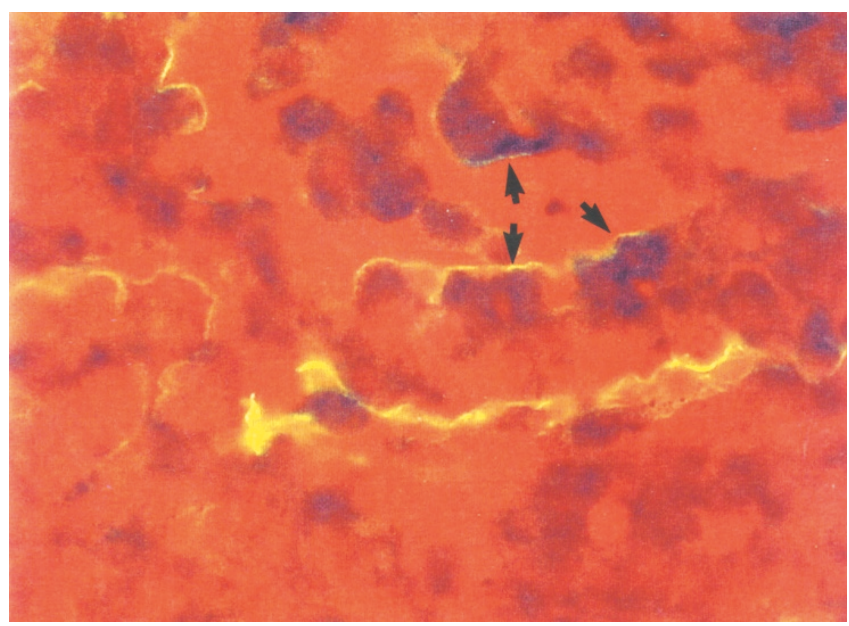

Proteinase-3 (PR-3) mRNA is expressed in pneumocytes type II in normal lung tissue (arrows). The expression of PR-3 mRNA was detected by nonradioactive in situ hybridization, and the pneumocytes type II were characterized by double-labeling with fluorescent lectins of Maclura pomifera (magnification, $60 \times 2.5$ ).

\section{Figure 4}

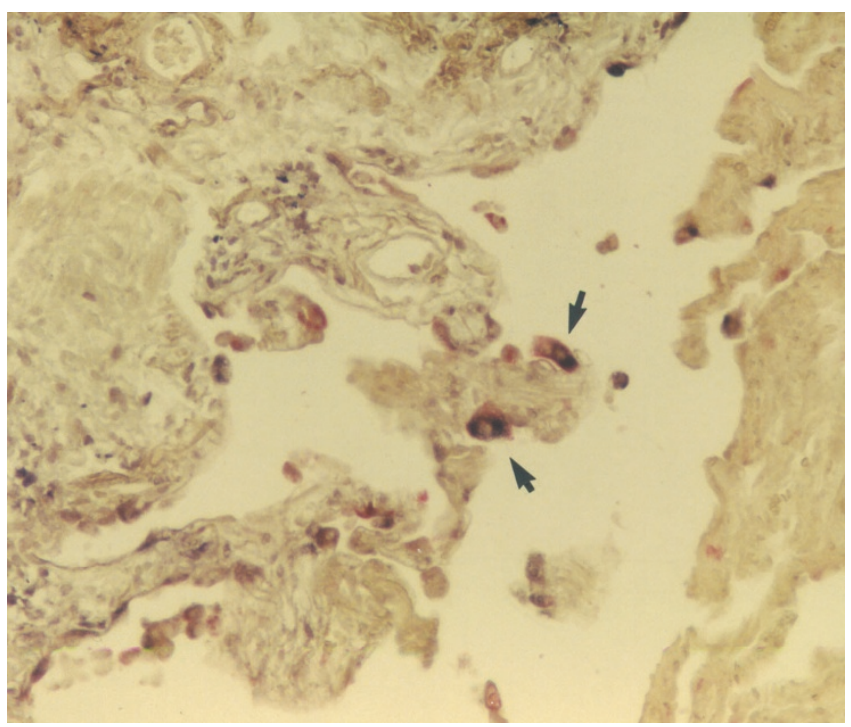

Proteinase-3 (PR-3) mRNA is expressed in macrophages (arrows).

Some cells express the PR-3 mRNA detected by nonradioactive in situ hybridization and double-labeling with CD68, a marker for macrophages (magnification, $40 \times 2.5$ ).

from some PR-3 mRNA expressing granulocytes, most of these infiltrating PR-3 mRNA expressing cells were macrophages (Supplementary Fig. 4). We found this kind of distribution of PR-3 mRNA expressing cells at sites of inflammatory infiltration, granulomas and vasculitis. At the

\section{Figure 5}

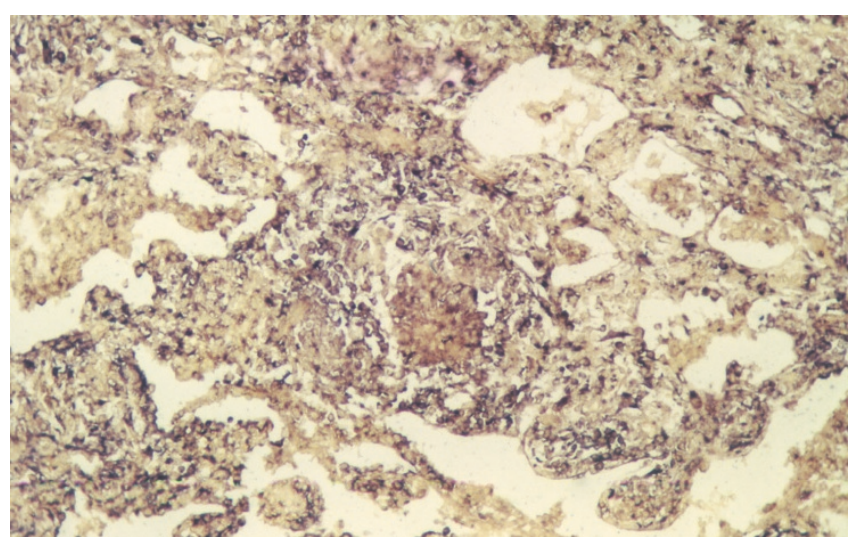

Proteinase-3 (PR-3) mRNA expression in a Wegener's granulomatosis lung specimen. The PR-3 mRNA was found strongly expressed and dispersed all over the lung tissue. The expression of PR-3 mRNA was detected by nonradioactive in situ hybridization (magnification, $20 \times 2.5$ ).

\section{Table 1}

Semiquantitative analysis of proteinase-3 mRNA expression in normal lung and Wegener's granulomatosis (WG) lung specimens

\begin{tabular}{lcc}
\hline Specimen & Normal lung & WG lung \\
\hline 1 & + & ++ \\
2 & $(+)$ & +++ \\
3 & $(+)$ & ++ \\
4 & + & ++ \\
5 & + & +++ \\
\hline
\end{tabular}

A representative area between 1,000 and 10,000 cells depending on the specimen was defined. In the representative areas, positive cells for PR-3 mRNA were scored in a semiquantitative fashion: -, no positive cells; $(+),<5 \%$ of cells positive; + , between $5 \%$ and $30 \%$ of cells positive; ++ , between 30 and $60 \%$ of cells positive;,$+++>60 \%$ of cells positive.

site of vasculitis, we detected PR-3 mRNA-positive cells that were different from inflammatory cells. From their histopathological appearance, these cells could be endothelial cells (Supplementary Fig. 4).

\section{Expression of the PR-3 protein in normal lung and WG tissue}

To visualize the PR-3 protein expression, we performed immunohistological experiments with a monoclonal antibody (WGM2) from mice, specific for PR-3.

We found the PR-3 protein in only few cells in normal lung tissue. According to the strong PR-3 mRNA expression, we also found an increased PR-3 protein expression in WG tissue (Fig. 6 and Supplementary Fig. 5). 


\section{Figure 6}

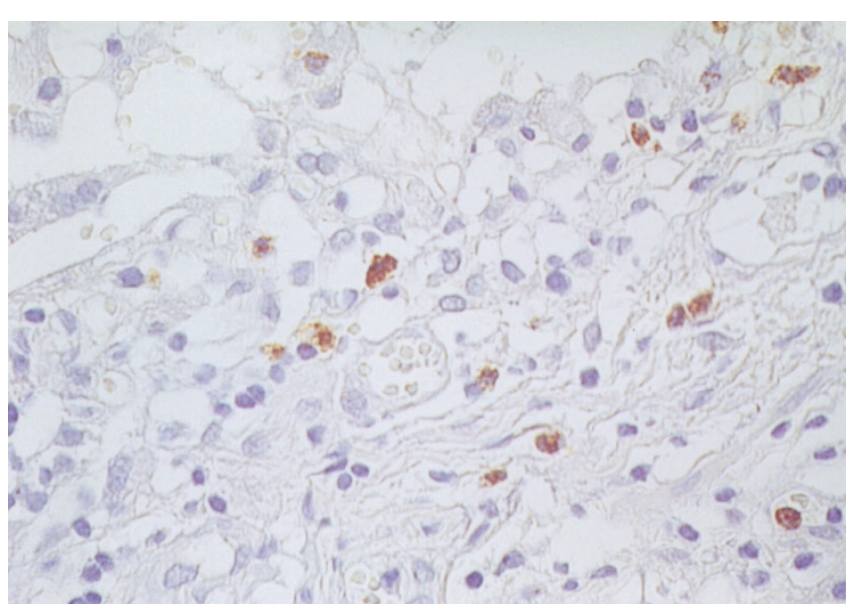

Proteinase-3 (PR-3) is also expressed on the protein level (brown cells). The PR-3 protein was detected by WGM2 antibodies, specific for PR-3 (magnification, $60 \times 2.5$ ).

\section{Discussion}

The diagnosis and classification of WG and related vasculitides were advanced considerably by characterization of serum antibodies that react with PR-3 (c-ANCA) [17]. It is not yet known whether ANCA are directly involved in the pathogenesis of WG or are merely an epiphenomenon [10]. One of the unresolved issues is the inability to explain the nonrandom, selected organ injury that defines the WG vasculitis and the concurrent, seemingly random, nature of injury within 'targeted' organs [18]. Little is known about the expression and distribution of PR-3 in the normal lung and in the lung tissue of patients with WG.

To contribute to this little-known issue, we examined the PR-3 expression in normal lung and lung tissue of WG patients, as the lung is the most frequent organ involved in WG [15]. In normal lung tissue, mainly pneumocytes type I and type II and just a few granulocytes and macrophages express PR-3. We could detect the PR-3 mRNA expression in pneumocytes especially at sites with an increased number of infiltrating macrophages. Speculatively, these cells could be responsible for initiating PR-3 mRNA expression; probably through changing the microenvironmental cytokine levels. Cytokines like interleukin-1 and tumor necrosis factor- $\alpha$, secreted from macrophages, can induce PR-3 mRNA in nonhematopoietic cells [19].

The different expression of PR-3 in pneumocytes could also be due to variations of transcription factors. One possible candidate gene could be PU.1, which regulates the PR-3 transcription in B cells and macrophages. The expression in other nonhematopoietic cells, in particular pneumocytes, has not been extensively investigated
$[20,21]$. Although expressed in a very small amount in normal lung tissue, a question concerning the function of PR-3 in normal lung arose, since the occurrence of a proteolytic enzyme like PR-3 should not be favorable in this tissue [22]. It is tempting to speculate that PR-3 could also play a role in microbiologic defense, since the enzyme also has an antimicrobial function [6]. Further studies are clearly needed to elucidate the function of PR-3 in pneumocytes.

After we had proven that PR-3 mRNA is expressed in normal lung tissue, we questioned whether the expression pattern is different in the lung tissue of WG patients. The examined specimens of patients with WG showed strong PR-3 mRNA expression, with a double to threefold PR-3 mRNA increase compared with normal lung tissue. Similar to our findings in normal lung tissue, we could demonstrate in lung tissue of WG patients that PR-3 is mostly expressed in pneumocytes type I and type II. PR-3 expression was pronounced at sites of inflammatory infiltration, vasculitis and granulomas. In comparison with normal lung tissue, however, there was a higher number of infiltrating PR-3 expressing cells, which were not pneumocytes.

Apart from some PR-3 expressing granulocytes, most of the infiltrating PR-3 expressing cells were macrophages. One explanation for the occurrence of PR-3-positive macrophages in inflammatory tissue is the invasion of circulating monocytes to inflammatory sites. Just et al. showed an upregulation of PR-3 mRNA expression especially in circulating monocytes, but not in neutrophils, in patients with cystic fibrosis [23]. We found PR-3 mRNA expression in and around vascular structures and vasculitic lesions, where most of the infiltrating cells were characterized as macrophages. However, a few cells seemed to be endothelial cells. This is in line with our recent findings of de novo synthesis of PR-3 in endothelial cells [24]. On the contrary, most endothelial cells (even at multiple sites of acute vasculitis with inflammatory cells, invading the vessel and the surrounding tissue), were negative for PR-3 mRNA. Recent studies on the kinetics and stability of PR-3 transcripts revealed PR-3 mRNA expression is only transiently upregulated in endothelial cells [25].

The histological features within the WG specimens varied considerably with different inflammatory infiltrates and with or without granulomas. The only apparent issue the WG specimens have in common is the upregulation of PR-3 throughout the whole specimen. The upregulation of PR-3 in the lung of WG patients may therefore reflect the selected organ injury, whereas the histological heterogeneity may represent a multiplicity of concurrent immune responses to a unique disease precipitant like PR-3.

As it is most probable that pneumocytes, vascular endothelial cells and renal epithelial cells are no longer only innocent bystanders but active participants in inflammatory reactions 
of autoimmune vasculitides such as WG, it is very important to study the expression pattern of PR-3 in other organs or tissues that are involved in the manifestation pattern of WG [26]. Schwarting et al. showed the in vitro expression of PR-3 mRNA in tubular epithelial cells and glomerular epithelial cells of the kidney [25]. In vivo experiments in the kidney revealed a PR-3 expression in distal tubular epithelial cells and in the glomerulum. The PR-3 mRNA expressed by human glomerular epithelial cells correlates with crescent formation in patients with WG [25].

We thus envision that the upregulation of PR-3 in parenchymal lung tissue in patients with WG, probably through an altered cytokine pattern, can lead to PR-3/ ANCA-mediated lung damage. Further in vitro experiments and functional studies with pneumocytes will show whether the interaction of anti-PR-3 antibodies with pneumocytes will also activate signal transduction events or the expression of chemokines or adhesion molecules.

In conclusion, we report for the first time that PR-3 mRNA, the target antigen for C-ANCA, is expressed by normal lung parenchymal cells and is upregulated in lung tissue of WG patients. PR-3 mRNA may therefore contribute to lung damage in WG and other ANCA-associated diseases via direct interaction.

\section{Acknowledgments}

The authors wish to thank Ms Huong Becker for excellent technical assistance and Dr E Csernok, Bad Bramstedt, for providing the monoclonal anti-PR-3 antibody WGM2.

\section{References}

1. Rao NV, Wehner NG, Marshall BC, Gray WR, Gray BH, Hoidal JR: Characterization of proteinase-3 (PR-3), a neutrophil serine proteinase. Structural and functional properties. $J \mathrm{Biol}$ Chem 1991, 35:9540-9548.

2. Campanelli D, Melchior M, Fu Y, Nakata N, Shuman H, Nathan C, Gabay JE: Cloning of CDNA for proteinase 3: a serine protease, antibiotic and autoantigen from human neutrophils. $J$ Exp Med 1990, 172:1709-1715.

3. Kao RC, Wehner NG, Skubitz KM, Gray BH, Hoidal JR: Proteinase 3. A distinct human polyporphonuclear leukocyte proteinase that produces emphysema in hamsters. J Clin Invest 1988, 82:1963-1973.

4. Bories D, Raynal MC, Solomon DH, Darzynkiewicz Z, Cayre Y: Down-regulation of a serine protease, myeloblastin, causes growth arrest and differentiation of promyelocytic leukemia cells. Cell 1989, 59:959-968.

5. Campanelli D, Detmers PA, Nathan CF, Gabay JE: Azurocidin and a homologous serine protease from neutrophils. Differential antimicrobial and proteolytical properties. J Clin Invest 1990, 85:904-915.

6. Gabay JE, Scott RW, Campanelli D: Antibiotic proteins of human polymorphonuclear leukocytes. Proc Natl Acad Sci USA 1989, 86:5610-5614.

7. Yang JJ, Kettritz R, Falk RJ, Jennette JC, Gaido ML: Apoptosis of endothelial cells induced by the neutrophil serine proteases proteinase 3 and elastase. Am J Pathol 1996, 149:1617-1626.

8. Laevitt Ry, Fauci AS, Bloch DA, Michel BA, Hunder GG, Arend WP, Calabrese LH, Fries JF, Lie JT, Lightfoot RW, Masi AT, McShane DJ, Mills JA, Stevens MB, Wallace SL, Zvaifler NJ: The American College of Rheumatology 1990 criteria for the classification of Wegener's granulomatosis. Arthritis Rheum 1990, 33:1101-1107.
9. Van der Woude FJ, Van Es LA, Daha MR: The role of the cANCA antigen in the pathogenesis of Wegener's granulomatosis. A hypothesis based on both humoral and cellular mechanisms. Neth J Med 1990, 36:169-171.

10. Kallenberg CGM, Brouwer E, Mulder AHL, Stegeman CA, Weening JJ, Cohen Tervaert JW: ANCA - pathophysiology revisited [review]. Clin Exp Immunol 1995, 100:1-3.

11. Falk RJ, Hogan S, Carey TS, Jennette JC: Clinical course of antineutrophil cytoplasmic autoantibodies-associated glomeruIonephritis and systemic vasculitis. Ann Intern Med 1990, 113: 656-663.

12. Sturrock AB, Franklion KF, Rao G, Marshall BC, Rebentisch MB, Lemons RS, Hoidal JR: Structure, chromosomal assignment, and expression of the gene for proteinas-3. J Biol Chem 1992, 267:21193-21199.

13. Mayet WJ, Schwarting A, Orth T, Sibelius U, Hattar K, Meyer zum Büschenfelde $\mathrm{KH}$ : Signal transduction pathways of membrane expression of proteinase 3 (PR-3) in human endothelial cells. Eur J Clin Invest 1997, 27:165-170.

14. Sibelius U, Hattar K, Schenkel A, Csernok E, Gross WL, Mayet WJ, Grimminger F: Influence of monoclonal antibodies against proteinase 3 on signal transduction and secondary cell reactions in human endothelial cells. Sarcoidosis 1996, 13:263270.

15. Burns A: Pulmonary vasculitis. Thorax 1998, 53:220-227.

16. Müller-Ladner U, Kriegsmann J, Tschopp J, Gay R, Gay S: Demonstration of granzyme a and perforin messenger RNA in the synovium of patients with rheumatoid arthritis. Arthritis Rheum 1995, 38:477-484.

17. Hoffman GS, Kerr GS, Laevitt RY, Hallahan CW, Lebovics RS, Travis WD, Rottem M, Fauci AS: Wegener's granulomatosis: an analysis of 158 patients. Ann Intern Med 1992, 116:488-498.

18. Hoffman GS, Specks U: Antineutrophil cytoplasmatic antibodies. Arthritis Rheum 1998, 41:1521-1537.

19. Schwarting A, Schlaak JF, Wandel E, Meyer zum Büschenfelde $\mathrm{KH}$, Mayet WJ: Human renal tubular epithelial cells as target cells for antibodies to proteinase 3 (c-ANCA). Nephrol Dial Transplant 1997, 12:916-923.

20. Srikanth S, Rado TA: PU.1 regulates the expression of the human neutrophil elastase gene. Biochem Biophys Acta, 1998, 1398:215-223.

21. Sturrock A, Franklin KF, Hoidal JR: Human proteinase-3 expression is regulated by PU. 1 in conjunction with a cytidine-rich element. J Biol Chem 1996, 271:32392-32402.

22. Ritter JH: Anti-neutrophil cytoplasmic autoantibodies and patterns of pulmonary disease. A spectrum of pathologic findings. Am J Clin Pathol 1995, 104:1-2.

23. Just J, Moog-Lutz C, Houzel-Charavel A, Canteloup S, Grimfeld A, Witko-Sarsat N, Cayre YE: Proteinase 3 mRNA expression is induced in monocytes but not in neutrophils of patients with cystic fibrosis. FEBS Lett 1999, 457:437-440.

24. Mayet WJ, Csernok E, Szymkowiak C, Gross WL, Meyer zum Büschenfelde $\mathrm{KH}$ : Human endothelial cells express proteinase 3 , the target antigen of anticytoplasmic antibodies in Wegener's granulomatosis. Blood 1993, 82:1221-1229.

25. Schwarting $A$, Hagen D, Odenthal M, Brockmann H, Dienes HP Wandel E, Rumpelt HJ, Meyer zum Büschenfelde $\mathrm{KH}$, Mayet WJ: Proteinase 3 mRNA expressed by human glomerular epithelial cells correlates with crescent formation in patients with Wegeners Granulomatosis. Kidney Int 2000, 57:2412-2422.

26. Mayet WJ, Helmreich-Becker I, Meyer zum Büschenfelde KH: The pathophysiology of anti-neutrophil cytoplasmic antibodies (ANCA) and their clinical relevance. Crit Rev Oncol Hematol 1996, 23:151-165. 


\section{Supplementary figures}

\section{Supplementary Figure 1}

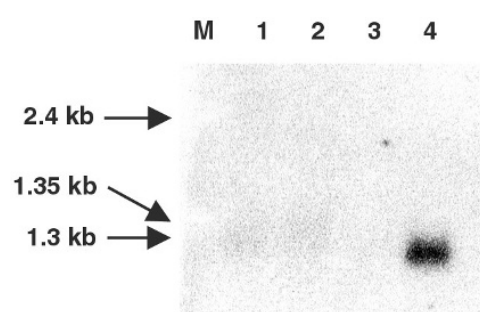

Northern blot containing approximately $2 \mu \mathrm{g}$ polyA RNA per lane from four different human tissues. Lanes 1-4 contain, in order, RNA from human heart, brain, liver and lung tissue. RNA size marker bands are indicated in the left margin of the blot (M).

\section{Supplementary Figure 2}

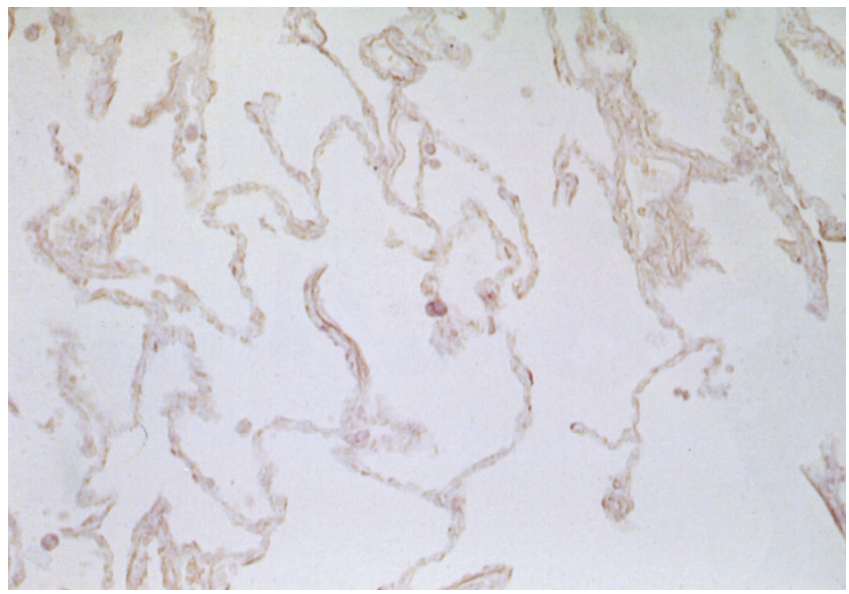

Human lung tissue (sense control; magnification, $20 \times 2.5$ ).

\section{Supplementary Figure 3}

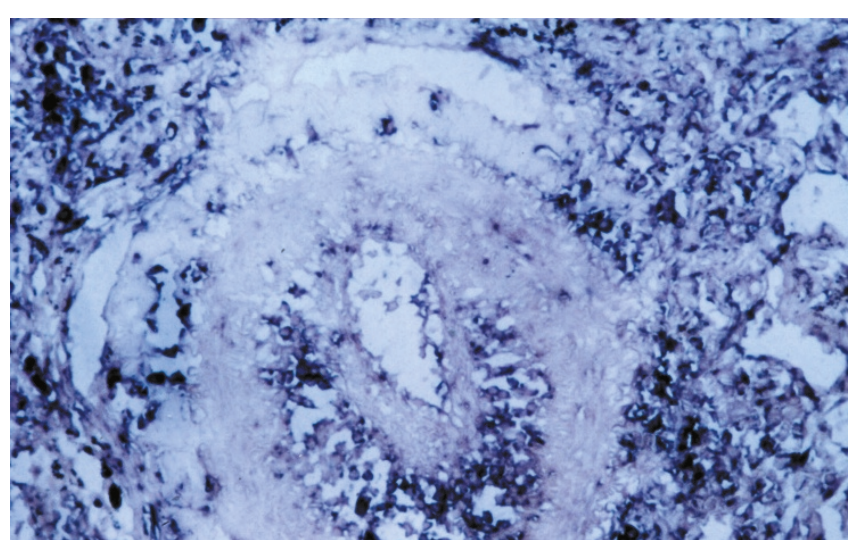

Proteinase-3 (PR-3) mRNA expression in vasculitic structures. Nonradioactive in situ expression of PR-3 mRNA is shown in the infiltrating and surrounding cells of the vessel (magnification, $40 \times 2.5$ ).

\section{Supplementary Figure 4}

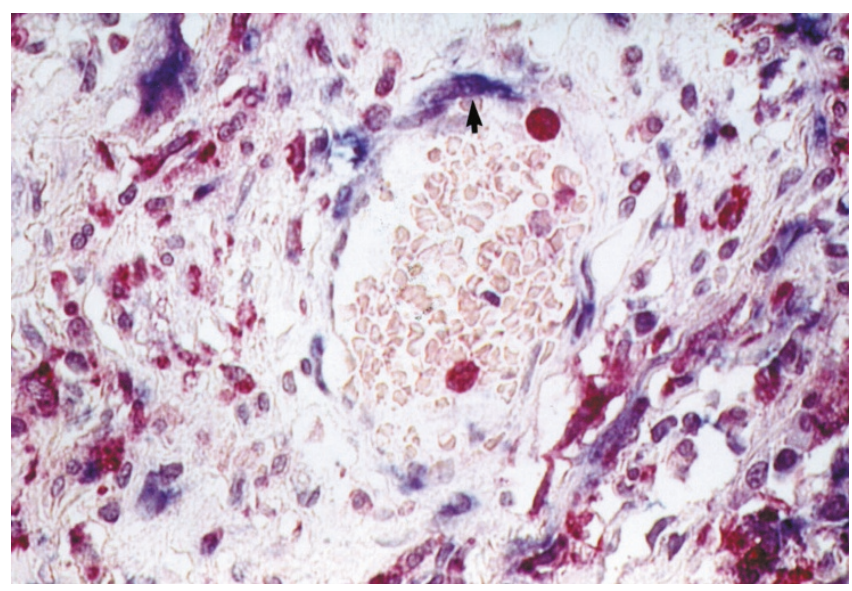

Proteinase-3 mRNA expression in macrophages and endothelial cells in a Wegener's granulomatosis lung specimen. The macrophages are double-labeled with CD68 (red cells). The histomorphological appearance of the marked cell points to an endothelial cell (arrow) (magnification, $60 \times 2.5$ ).

\section{Supplementary Figure 5}

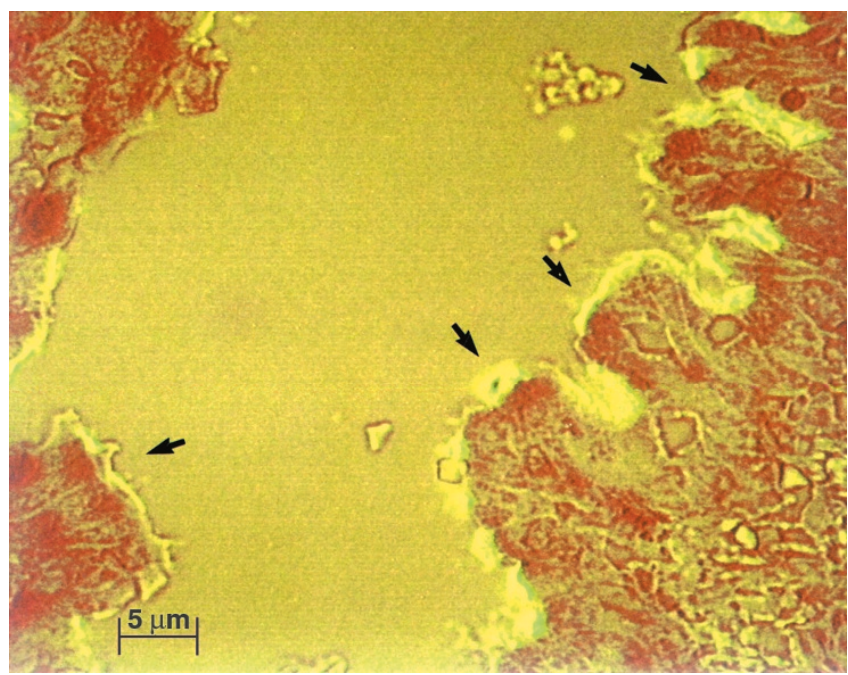

The proteinase-3 (PR-3) protein is expressed in pneumocytes type I in Wegener's granulomatosis tissue (arrows). The expression of PR-3 protein was detected by immunohistological staining with WGM2 antibodies, and the pneumocytes type I were detected by doublelabeling with fluorescent lectins of Bauhinia purpurea (magnification, $60 \times 2.5)$. 